\title{
THE DIVORCE PROBLEMS: \\ REASONS AND THEIR CONSEQUENCES \\ FOR THE SOCIALIZATION OF CHILDREN
}

\section{Suiatynova Kateryna ${ }^{1}$}

DOI: http://dx.doi.org/10.30525/978-9934-571-27-5_51

Abstract. The purpose of the paper is to identifying and addressing urgent issues in the socialization of children who are brought up in families of divorced parents; clarification of features of the socialization of preschool children in families of divorced parents, identifying its negative aspects. The before, most of the couples who divorce have children, although the number of such pairs is reduced. In most cases, divorcing couple have one child, due to the unigeniture of Ukrainian families. However, in rural areas, the unigeniture is higher than in the cities, so the impact of family disruption on the development of the younger generation is more powerful. The vast majority of social characteristics of children experiencing divorce, shows, alas, about the negative effects on the child's personality. There is a specific system of relations between mother and child in families after divorces; there are some patterns of behavior that sometimes are an alternative to norms and values that underpin the institution of marriage. We have carried out a survey among the group of experts due to insufficient amount of information about types, forms of social work with divorced families and problems of socialization of children whose parents have divorced. So we have asked the experts who can find out these issues qualified. The second group of respondents was created from parents of preschool children who were in the state of divorce at the time of the survey. Both groups of respondents were offered a questionnaire, which was consisted of four blocks of questions. The first block was aimed to identify their opinions about the divorce situation in general, and the issues that they have to solve independently; the questions of the second block allowed us to obtain some information about the causes and consequences of divorce and the reaction of children

${ }^{1}$ Candidate of Pedagogical Sciences,

Senior Teacher at Department of Social Pedagogics and Social Work,

Department of Preschool Education,

Kryvyi Rih State Pedagogical University, Ukraine 
of senior preschool age; the third block of questions was devoted to clarifying the perspectives of divorced parents of the senior preschool children in the work of educators, practical psychologists and social teachers of preschool institutions. We can conclude that both parents and their children in a divorce situation need effective social rehabilitative specialist help from the social services in various fields. The analysis of psycho-pedagogical work allowed concluding that social characteristics of children experiencing the divorce of their parents reveal the negative nature of its influence on the child's personality. The parental divorce reduces the number of family communication, limits the full functioning of the family and affects inevitably at the socialization of children, inadequate assimilation of the sex-role attitudes and behaviors.

The scientists have identified two vectors of negative consequences of the parental divorce for the socialization of children - short term and long term. In addition, a few specific features in the life of a child related to the fact that a family has only one parent are highlighted, namely: firstly, the state of one of the parents, who will feel lack of moral, social and material support of the other spouse. Single father has to seek some help outside the family. The society, in turn, will affect unmarried mother and her husband who has left the family. Secondly, the child is exposed to social discrimination associated with the absence of father or mother. Thirdly, the child is deprived of the opportunity to observe a close and harmonious relationship between two adults that can affect his/her own marriage. Fourthly, if there is a parent of the opposite sex with a child in the family, she/he will have no ability of gender identity.

\section{Introduction}

The deterioration of the socio-economic, political processes in Ukraine, the loss of moral-ethical foundations, have a negative influence on the population. There are some factors that predetermine the increase of the number of divorces. They are the change of living and psychological conditions of family life, the situation in the East of Ukraine since 2014, the worsening of health, the rising prices, the absence of values, the change of family values, the migration of Ukrainian population, the unmarried motherhood, the spread of informal marital and family relations, low level of responsibility, as well as the legal, moral and aesthetic responsibilities of parents.

A lot of children experience an intense stress because of a large number of divorces every year. Majority of couples that break up have children, 
and, consequently, every year thousands of children go through the parents' divorce. Although the number of such children is gradually decreasing, this is not due to a decrease of the number of divorces but also to the decline of the amount of children in Ukrainian family [44, p. 12].

The research problem is determined as follows, identifying and addressing urgent issues in the socialization of children who are brought up in families of divorced parents; clarification of features of the socialization of preschool children in families of divorced parents, identifying its negative aspects.

\section{The distribution of divorces by number of children in Ukraine}

Thus, 192194 divorces were registered in 1990 in Ukraine, according to the State statistics service of Ukraine, 224649 divorces - in 1992, which is the highest index during the analyzed period. Since 1997, the falling of divorces number began - 186371 , and in a few years there were fluctuations again: in 2000 the number of divorces amounted to 1956928 , in 2016 - 129 997. The general marriage rate - a number of divorces per 1000 population - was 3.7 in 1990, 4.3 in 1992, 3.7 in 1997, 4.0 in 2000, 2.7 in 2010, 4.0 in 2011, 3.3 in 2016 (excluding the temporarily occupied territory of the Autonomous Republic of Crimea and Sevastopol and the data of the Donetsk and Lugansk regions). The least number of divorces was registered in 2010 - 126068 , the general marriage rate was 2.7. But in 2010, the law "About the state registration of acts of civil status" was adopted in Ukraine, which changed the procedure of registration of divorce that affected to the system of statistical accounting. According to the new rules, information about the divorce that have occurred by court order, is not received in the Registrar's office that have issued the certificate of divorce in all cases, have accumulated statistical information and passed it to the statistics. As a result, complete data on the number of divorces for the year 2010 are not available. In 2011 there were only 182534 (4.0\%) divorces, a "surge" was observed, partly caused by these changes in 2012 168546 (3.7\%) of divorces, in 2013 - 164939 (3.6\%), in $2014-3 \%$, in $2015-3.3 \%$ (excluding the temporarily occupied territory of the Autonomous Republic of Crimea and Sevastopol and the data of the Donetsk and Lugansk regions), and in 2016 - 129997 (3,3 \%) divorces (excluding the temporarily occupied territory of the Autonomous Republic of Crimea and Sevastopol and the data for the Donetsk and Lugansk regions). 
The divorce problems: reasons and their consequences for the socialization...

Over the past 27 years the divorce rate was $57 \%$ in 1992, in $1998-$ $57,87 \%$, in $2000-71.28 \%$ of registered marriages: 274523 marriages had 195693 divorces, in $2004-61,18 \%$, in 2012 the number of divorces was $60.56 \%$, in $2010-41,20 \%$, in $2012-60.56 \%$, in $2013-54,21 \%$, in $2015-43,32 \%$ (excluding the temporarily occupied territory of the Autonomous Republic of Crimea and Sevastopol and the data of Donetsk and Luhansk oblasts), in 2016 - 56,65 \% (excluding the temporarily occupied territory of the Autonomous Republic of Crimea and the city Of Sevastopol and the data for the Donetsk and Lugansk regions). We have to consider that it is necessary to bring to notice that a high divorce rate is due to the high level of registered marriages.

Most couples, who get divorced, have children and, consequently, every year thousands of minor children are involved in the divorce process of their parents. Therefore, 79139 families had one child among the 173163 divorces in 2004, 19102 families had two children, 10054 families had three and more children [37, p. 34]. We have no complete characterization of the marriages that have fallen apart after 2009. The analysis of the distribution of divorces by age of spouses, length of marriage and number of children in the couple in Ukraine can be done only until 2010 (Table 2.1).

Table 2.1

The distribution of divorces by the number of common children in Ukraine in 2004-2009

\begin{tabular}{|c|c|c|c|c|}
\hline \multirow{2}{*}{ Year } & \multirow{2}{*}{$\begin{array}{c}\text { Total } \\
\text { registered } \\
\text { divorces }\end{array}$} & \multirow{2}{*}{$\begin{array}{c}\text { Not have common } \\
\text { children, \% }\end{array}$} & \multicolumn{2}{|c|}{ Have children: } \\
\cline { 4 - 5 } & & One child, \% & $\begin{array}{c}\text { Two children } \\
\text { and more, \% }\end{array}$ \\
\hline 2004 & 173163 & 41,6 & 45,7 & 12,7 \\
\hline 2005 & 183455 & 40,3 & 47,5 & 12,2 \\
\hline 2006 & 179123 & 41,4 & 47,2 & 11,4 \\
\hline 2007 & 178364 & 42,7 & 46,7 & 10,6 \\
\hline 2008 & 166845 & 44,1 & 45,4 & 10,5 \\
\hline 2009 & 145439 & 45,1 & 44,8 & 10,1 \\
\hline
\end{tabular}

The source: the State statistics service of Ukraine [11; 26]

The before, most of the couples who divorce have children, although the number of such pairs is reduced. In most cases, divorcing couple have one child, due to the unigeniture of Ukrainian families. However, in rural 
areas, the unigeniture is higher than in the cities, so the impact of family disruption on the development of the younger generation is more powerful $[25$, p. 68].

The problem of divorce, its effects have been explored by N. Bashkyrov, N. Valetas, D. Vydra, T. Gavrylova, O. Grygorieva, T. Gurko, I. Dementieva, K. Kuznetsova (K. Kamyshova), L. Prokofieva, L. Savinov, A. Synelnykov, S. Sedel'nikov, N. Solovyev, V. Tseluyko etc. The fundamental writings of authors on this issue is devoted to the study of the relationship between social well-being, child development and influence of a divorce. The understanding of this aspect is complicated by the fact that in many studies all children from single parent families are considered as a single group and their difficulties are not differentiated and identified.

According to V. Tseluyko, A. Vasylenko, O. Dementieva, the children experience of parents gap ranges from lethargic depression, apathy to severe hyperactivity, negativity and showing disagreement with their opinion [39, p. 21]. The scientists, such as O. Grygorieva, I. Dementieva, Yu. Konusov, N. Mykhailova and others notice that children feel fear, abandonment, shame, loneliness, guilt, sadness, aggression directed at the relatives and other children $[5$, p. $18-19 ; 8$, p. 112; 9, p. 11-15; 16, p. 156; 23, p. 20-23].

A divorce attracts an attention of society due to the fact that it is associated with a number of negative social phenomena such as the fertility decline, the weakening of the educational potential of the family and so on.

The divorce is made by the bodies of state registration of acts of civil status or by court order. The marriage is terminated at the day of the divorce registration in the body of state registration of acts of civil status in the event of dissolution of marriage by the body of the state registration of acts of civil status. In the event of marriage dissolution by the court, it is terminated at the day of entry into force of the judgment of divorce [24, p. 72].

So, a divorced family is a family, which arose as a result of the legal dissolution of the marriage by the spouses (with or without children) by mutual agreement or at the initiative of one of them [30, p. 21].

\section{The effect of divorce on the child's personality}

The vast majority of social characteristics of children experiencing divorce, shows, alas, about the negative effects on the child's personality. So, all psychologists and professionals working with the consequences of 
family breakdown, report high levels of anxiety that is typical for children from families of divorced parents [8, p. 112].

There is a specific system of relations between mother and child in families after divorces; there are some patterns of behavior that sometimes are an alternative to norms and values that underpin the institution of marriage [43, p. 131].

In the thesis K. Kuznetsova has conducted a sociological analysis of divorces in modern society, and has emphasized two blocks of negative effects of divorce on the socialization of children, has classified families of divorced parents by criteria etc [20]. A systematic analysis of sociological, psychological, pedagogical, legal, medical literature has allowed K. Kuznetsova to allocate two large blocks of the negative consequences of parental divorce for the socialization of children - a short term and a long term. The first block is associated with the peculiarities of their reaction to the conflict between the parents, which intensifies before divorce, to the procedure of the divorce and the adaptation after it. The long-term impact of the divorce is caused by the accumulation of an effect of the lack of male influence on the process of education and socialization of the child over many years.

A psychologist and a psychotherapist V. Ilin calls a divorce of men and women as a conscious exception of a relative from the family history. In a situation when spouses are getting divorced "not like decent people", a woman sometimes decides to strike out her ex-husband not only from her life but the lives of their children. A man, in turn, can remove a woman not only from his circle of contacts, but also erase her from his memory $[14$, p. 173]. The damage of the clan structure, the distortion of the tribal identity, the rejection from ancestral history as the result of exposure to an individual or family group of the most dark and archaic structures of the personal and collective unconscious inevitably affects the whole family, and personal destiny of each members [14, p. 176].

A divorce as a factor influencing children does not provoke any discussion among scientists. If family breakdown changes for the conditions of the formation of child's personality for the best, helps to put the end to a sharp impact on his mentality of parental conflicts, in these cases it can be regarded as a benefit $[2$, p. $125 ; 39$, p. $12 ; 42$, p. 26]. But even in this situation, according to most authors, the break-up of parents is a strong stress in a child's life, an impetus for the development of deviant behavior [5, p. 18-19; 9, p. 11-15; 10, p. 18; 13, p. 119; 16, p. 153; 42, p. 8]. 
Foreign authors have identified some factors that influence the adaptation of children to parental divorce fact. They are the nature of the interaction between parents and children, the emotional state of the parents, the present children problems, the social training of parents and children, the inadequate attention to the child, the loss in a divorce, its suddenness [12], N. Ratter [28, p. 206].

K. Vitek [4], Z. Marova [21], Z Mateichik [22], N. Ratter [28], G. Figdor [36] have made the greatest contribution to the study of the effect of parental divorce among foreign researchers; they have focused on the study of the forms, means and methods to prevent and compensate negative effects of divorce on all family members. However, these studies should be viewed through the prism of foreign cultures, their life style, economic factors, and the motivation of marriage (emotional background or economic needs) and so on.

Therefore, D. Vidra, a translator of scientific work of G. Figdora, has interpreted the problems of divorce in an accessible form, focusing on the recommendations to the spouses how to overcome their own depression caused by the divorce in her work [3]. The researcher has noted that "children are experiencing not just a parental divorce; they are experiencing their own divorce with one of them" [3, p. 38]. During the divorce of their parents, a child feels sadness, anger, guilt and fear, and the awareness of their secondary importance, helplessness to prevent his parents' divorce leads to rage. The rage can be directed at both parents, sometimes it is directed at one parent, who the child believes is guilty in divorce [3, p. 38].

A researcher Z. Marova [21] has noticed that a divorce is often necessary for a child if it is really desired for parents. The child feels more miserable in the family where we always have some tension and recurring conflicts. The divorce in such circumstances is a necessary solution. The age of the child, the consciousness and consistency of adults play an important role during the divorce. Mother and father should take a clear position against what happened because it is impossible to keep a secret about your broken relationship from your child. Any explanation, justification in the future usually cause a sense of insincerity and excite suspicion in a child.

The simplest is the situation, according to Z. Marova when parental divorce occurs in early age. The development, education, learning, and discovering the world in new conditions help the child to learn faster old affec- 
tion and to get used to new conditions of life, therefore, the child weans from the father, who has left quickly.

The divorce in families with adolescent children must be gone through better than in families with small children, according to Z. Marova. During adolescence, the child is too sensitive, lends himself to various influences easily, he/she is very impressionable, reacts quickly to happy or sad events. He/ she has a particularly keen sense of justice. So, in adolescence, the divorce of the parents influences the child in the deepest and most negative way.

Z. Mateichyk has similar views regarding the fact that parental divorce is more expedient to carry out while there are children of preschool age than a school age in the family [22]. The family scenes cause the greatest harm to the further development of the child which often accompany the divorce of their parents and which the children often observe. There are children who perceive their parents' divorce easier than it has been expected. The first reaction of the child is assumed to be weak, and over the years, it will grow and become dangerous.

The problem of the divorced family is that a mother cannot replace a father because she is a woman, and because one of the parents cannot replace two. Each of them brings into the family his/her personality, his / her diversity of feelings and thoughts, interests and knowledge, actions and deeds. The absence of one of the parents cannot be replaced. The child has less opportunity to become familiar with the various options of social experience, and most importantly, with the party of intimate and emotional sphere of his / her family, which is created by relations of spouses. This vacuum in the divorced family influences negatively on the children preparing to family life. This situation, which is characterized by the absence of a clear model of relationships between men and women, creates a strong risk that a deformed (or spiritually depleted or cut off from life - more romantic and idealized) views on marriage and family are being laid in children, they will impact on the development of her / his own family in the future.

The majority of single mothers has the ability to give their child a necessary physical and moral education. If a single mother is busy with her personal problems, she takes less care about her child, or totally ceases to worry about her / him. Some mothers, on the contrary, overwhelms the child with experiences, accelerate his / her development because of the fear of little worry. Such situation is as bad as its shortage, whereas you can generate indifference and cause resistance. Therefore, the scientists have 
noted on a special personal influence of a mother on the formation of certain qualities of child's personality.

Analyzing the problems of motherhood, F. Horvat points to the crucial mother's role in the development of child's personality: "An educational process of each child takes place in the appropriate social environment; a condition of which depends on the women almost in every family... A lack of maternal attention makes a child to feel bigger need in spiritual communication. If this need remains unmet in early childhood, all mental development may be disturbed" [41, p. 9].

From a practical point of view, according to S. Mateichik, it is convenient for a single mother, when her child and her education are not the cause of conflict. Nevertheless, raising a child in a single-parent family has a negative aspect. If nobody complicates and spoils parental duties of a single mother, respectively, no one corrects. A light inurement of various skills to a child does not mean that they are well formed and useful. As a result, of course, we have a big risk: one-sided education.

A psychotherapist M. Ratter has called a few specific moments in the life of a child related to the presence of only one parent in the family, namely: firstly, the state of one parent, who is in short supply of moral, social and material support of the other spouse. A single father has to seek some help outside the family. Society, in turn, will affect unmarried mother and her husband who left the family. Secondly, the child is exposed to social discrimination associated with the absence of father or mother. Thirdly, the child is deprived of the opportunity to observe a close and harmonious relationship between two adults that can affect her/his own marriage. Fourthly, if the parent of the opposite sex remains in the family, the child will have no opportunity to gender identity [28, p. 206]. According to N. The Rutter, single parenting and the effects of such education is less clear and less complicated than commonly believed. The fact of having one or both parents is perhaps less important for child development than the nature of the relationship between father and child or the style of parental behavior [28, p. 207].

In exploration 1972, western scientists have proved the negative influence of the family in which there is only a mother, but no father. So, L. Bumpass and J. Sweet have found a greater likelihood of divorce among those who experienced parental divorce in childhood [45, p. 132]. John Hayes has explained the impact of parental divorce only for local residents, blacks, who belong to the middle class [45, p. 131]. 
In 1988, S. McLanahan and L. Bumpass concluded that the divorce has a greater negative impact on a teenager than a child, because older people draws attention to the relationship of representatives genders [45, p. 134].

The parental divorce is certainly a risk factor that often hampers a normal personal and emotional development of a child. A disintegration of a family as a primary agent of socialization in this case - is a total destruction of an old social world, a loss of psychological support, a need to solve new problems for a child [20].

The Independent Institute of social policy with its partners have conducted a number of studies and have concluded that inuremented in early age behavioral stereotypes are left with the child for all his / her life (the child learns family roles and models them in the sphere of private partnerships by the example of their parents' interaction) [18, p. 65].

The frequency of meetings of men with children after divorce is reduced more than 2 times in the case of remarriage of the father, and the birth of children in a new partnership leads to further deterioration of relations. The survey data have revealed some regularity: the men meet with the children of a new wife (partner) who were born before this marriage, 2.5 times more often than with their families and children, from a previous marriage, which has collapsed. Thus, we can conclude that the relationship of a husband and children, as a rule, depend on women: on the one hand, from that who is now close to and attracts her husband to the relationship with his children, and on the other hand from his ex-wife, who may hinder the meeting of the father and the children [18, p. 65-66].

The researchers L. Prokofieva and M. Valetas have conducted a survey among men about the frequency of their meetings with the children after divorce with the woman. According to respondents, one third of men often meet with children, almost half meet rare, and $17 \%$ do not see them at all. The frequency of meetings depends on the time that has elapsed after the divorce, the meetings become less frequent, and this fact does not depend on the place of father's residence. Women have pointed 2 times more often to the absence of any relationship of fathers with children answering a similar question regarding the frequency of meetings ex-husband with children.

The reasons for these responses L. Prokofieva and M. Valetas explain the different value that you put in the word "to see": women understand it wider - "to be involved in" a child [27]. 
A researcher I. Dementieva has noted that many authors of the studied problem have found that "the tendency to divorce" is transmitted from generation to generation, so the children, whose parents are divorced, get divorced more often than who grew up in a strong family. One explanation of this fact is that they already have an idea about the possibility of divorce and a low sense of responsibility regarding the marital relationship after the divorce of their parents and before getting married.

So, E. Bern has described "the phenomenon of parental programming", which indicates an unconscious assimilation of the identity of attitudes, values, beliefs, behaviors of parent families. G. Fomyuk, O. Kuzina have explained this phenomenon, they have noted that the components of socio-psychological stereotype is laid in childhood, when the formation and development of psycho-reflecting realm (subconscious) by their dynamics are in advance the formation and development of conscious intellectual, emotional, volitional spheres. These scientists say about the existence of a mechanism of an unconscious child's perception of the family traditions, personality traits of parents etc. Parents teach children some disrespect to the opposite gender unconsciously in the "problem family" that has a negative effect on their future married life [29, p. 56].

In 2004, there were a unique socio-demographic survey of Russian families "Parents and children, men and women in family and society,» which examined the causes of early marriage, early appearance of children, children before marriage, divorces and re-marriages. In the result of the study, the hypothesis about the gender and age differences of children's reactions to the collapse of the parental family was confirmed. So, men who have experienced parental divorce at the age from 3 to 13 years of age have the risk of collapse of their own families in 1.6 times higher than those whose parents have not divorced. Men who have experienced parental divorce at another age $(0-2,14-24$, older than 25 years $)$ have not shown statistically significant elevated odds of divorce. By contrast, women are more likely to repeat the fate of mothers in the case if they were from 14 to 24 years at the time of their parents' divorce [6, p. 7].

A researcher F. Fomin proposes to consider the divorce as not always a wrong decision: there are some situation when it is referred to domestic violence, sexual harassment, various kinds of exploitation, and so on. However, the gap in the marriage relationship always bears the psychological 
stress not only for all members of the family, but for the inner circle - relatives, friends [31, p. 85].

According to F. Fomin, children, growing up in families of divorced parents, learn a model of the relationship of their parents and are not likely able to build a real partnership family in the future, and will continue to increase the number of unhappy families [38, p. 85].

There are some problems among the psycho-pedagogical ones of minors arising because of the divorce of their parents. They are a complication and deformation of the child's occurrence in social environment, a social deadaptation to daily life [5, p. 18-19; 8, p. 111; 40, p. 29]; a formation of defects of character and moral development, that is manifested in unformation of altruistic and humanistic properties, in the absence of positive experience of collaboration, cooperation, mutual actions and decisions, in choosing the role of the permanent victim in future [7, p. 19]; social discrimination associated with the absence of father and mother [9, p. 19]; the increased risk of antisocial behavior as a response to the conflict situation in the family before the divorce, procedure of divorce, as well as for your special social status [9, p. 19; 34, p. 439; 38, p. 25]; child neglect [208, p. 134]; some difficulties in relationships with adults, and half brothers and sisters in a situation of polypaternity $[10 ; 17 ; 23]$, one-sided education, the feminization of boys, sexual identity disorder [7, p. 20; 32, p. 134; 33, p. 317-318].

The children who have experienced a divorce or a divorce and a remarriage of parents, are at greater risk to run into psychological problems than the children from strong families. There are authoritarian or too liberal attitude in single-parent families (where we have one parent) more often than in usual families [35].

The children from single-parent families, getting married, express a firm decision not to follow the example of their parents in a family relationship at the beginning. However, after some time, they likewise leave their families because of the lack of moral responsibilities to their children, as those duties have not been fulfilled towards them. The factor of parental divorce increases the likelihood of the children's divorce to $27 \%[19, \mathrm{p} .86]$.

V. Tseluyko's opinion about the life of a child in single-parent divorced family boils down that the child receives a psychological trauma because parents for any reason could not or did not want to live together. The consequences of divorce affect a child's psyche, causing the appearance of feelings of inferiority, shame, fear. There are no severe consequences only in 
cases when a child perceives a parental divorce as a liberation from the nightmare [43, p. 107-108].

The feature of incomplete divorced families is the fact that the mother often returns with the children to their parents after divorce. According to $\mathrm{V}$. Tseluyko, we should remember that sometimes the moral and material support of parents assists the divorce. A characteristic phenomenon of the relations in a single-parent family is the inversion of the educational role, when grandma takes the role of mother with authoritarian personality traits, and mother or grandfather perform the role of the father with a solid character and high integrity. The boys are in the most traumatic situation, who are deprived of maternal love and parental authority. Mothers usually prevent the meeting between father and son, and show the boys more austerity, which can be regarded as a reaction to the rejection of the unwanted traits of the former husband. Therefore, the mothers often use the menace, condemnation and physical violence towards the boys. The mothers are more carefully towards the girls. However, the children who have stayed with mother, often experience tension and a sense of emotional dissatisfaction. An increase of mental stress and the appearance of neurotic and behavioral disorders will be the consequence of the lack of emotional recognition and understanding on mother's side [43, p. 109].

In the West, the "common legal" custody of the children after a divorce is practiced. Such custody means that the children live mostly with one parent, but the father and mother jointly make decisions concerning their education and upbringing. The "common legal" custody implies that the children may live with each parent in turn. The parents share their children in case of "split" custody: the mother usually takes the girls and the father - the boys. However, as studies have shown, partial custody often has negative consequences for siblings, so it should be used in extreme cases [46, p. 512].

An American sociologist and futurologist D. Coates has described the current state of the family and family relations on the example of the USA. The researcher has noticed that the blended families are increasingly becoming a norm as the result parents' divorce, who re-marry, but maintain relationships with a former partner and his / her new family or bring together the children from different marriages [15].

According to T. Andreeva, the formation of an emotionally healthy child depends on his / her relationship with both parents. Ninety percent of children, whose parents are getting divorced, have experienced a short-term shock with 
pain and instinctive fear after having got to know about their parental divorce. More than half of children feel alienated and abandoned among the $50 \%$ of parents who stops to visit them in three years after their divorce.

The researcher has argued that boys, who are deprived a sufficient communication with their father in childhood, either learn a "female" type of behavior or create a distorted picture of male behavior as antagonistic opposite women and do not perceive what the mother is trying to instill. These boys are less mature and motivated, do not feel safe themselves, are less enterprising and balanced, the ability to empathize, to control their behavior develop hard. It is harder for them to fulfill their paternal obligations.

The girls, being brought up without a father, form an idea of masculinity less successfully, they have less chance to understand correctly their husbands and sons, to play the role of wife and mother in future. A father's love to daughter is important for the development of her self-awareness, self-confidence, the formation of her image of womanhood [1, p. 152].

The only child in the family becomes the most vulnerable to family breakdown, as V. Tseluyko has said. Those children who have siblings tend to cope better with the divorce of their parents: in such cases, children splash out aggression or anxiety on each other, this fact reduces greatly an emotional stress and a chance of nervous breakdowns [43, p. 134].

Long-term psychological and pedagogical consequences of divorce are characterized by the scarcity (absence) of contacts with the father, making it difficult for a child to take a significant part of the social experience, not only because of the absence of direct influence of another mentor, but also because of the impossibility of perceiving the practice of parental, marital interaction.

The rate of identification of children with their parents, according to I. Dementieva, is one of the main criteria of the effectiveness of family education in which the child expresses its acceptance of the moral and ideological norms of their parents. The implementation of this part of the educational process in a single-parent family is deformed due to the absence of the parent $[9, \mathrm{p} .109]$. The researcher argues that the divorce is not always a factor that prevents the full socialization of the child. The sons, who have been left without a father, take the role of "owner" of the house, who is responsible for the welfare of the family more often [9, p. 112].

All of the previously mentioned allow confirming that the process of social development of the child is a complex phenomenon during which an understanding of objectively set norms of the human community and the con- 
stant discovery of the world of humans by him/her and his / her own world, the affirmation of himself / herself as a social entity is occurring. The process of socialization occurs in the child's interactions with social institutions in the process of acquiring knowledge and experience of socially approved behavior. The family is a major social institution for a child under school age.

\section{Survey methodology}

We have carried out a survey among the group of experts due to insufficient amount of information about types, forms of social work with divorced families and problems of socialization of children whose parents have divorced. So we have asked the experts who can find out these issues qualified. We note that the group of experts has those professionals who have an idea about the problems of families with preschool children in situations of divorce, namely: social workers, psychologists and educators of preschool educational institutions. A blank of experts' survey has been developed to carry out the survey in the expert group. The questions of this survey have been aimed at identifying the opinions of experts concerning the characteristics of the social status of families of divorced parents, as well as the nature of the effects of divorce on emotional and social-moral well-being of preschool.

The second group of respondents was created from parents of preschool children who were in the state of divorce at the time of the survey. It included: a) by the gender: 98.5 per cent of women, 1.5 per cent of men; b) by the age: 14.5 per cent of women aged $18-24$ years old, 25.3 per cent of women aged 25 - 30 per cent, 45.3 per cent women, aged 31 - 39 years, 22.4 per cent of women aged 40 - 49 years, 6.2 per cent of women older than 50 years; c) by the level of education: 33,1 per cent have complete secondary education, 39.1 per cent - specialized secondary education, 25.6per cent of - have higher education, 12,3 per cent - incomplete higher education, and 2.5 per cent have a degree; d) the number of children in the family: 74.3 per cent have one child, 23.1 percent have two children, 2.1 percent - three children.

Both groups of respondents were offered a questionnaire, which was consisted of four blocks of questions. The first block was aimed to identify their opinions about the divorce situation in general, and the issues that they have to solve independently; the questions of the second block allowed us to obtain some information about the causes and consequences of divorce and the reaction of children of senior preschool age; the third block of ques- 
tions was devoted to clarifying the perspectives of divorced parents of the senior preschool children in the work of educators, practical psychologists and social teachers of preschool institutions.

First of all, the experts have been asked to highlight problems that are inherent in single-parent families, and those peculiar divorced. According to the responses, the most pronounced problems in divorced families, according to experts, are the following: a dispute about the place of residence of the child and participation in his / her education, a division of property, a possibility of transferring the child to father / mother who has gone from the family, a changing of child's surname, an undermined confidence of the child to the parents, a problem of the relationship of the child with the stepfather (stepmother), some reorganization of the family and family ties due to the divorce.

We have received the majority of affirmative answers on the survey question "Are you able to overcome difficulties arising because of the divorce?" regarding the importance and necessity of external support for families in a divorce situation. Only 14.2 per cent of parents, who are divorced, are confident in the availability of resources for individual solving of family problems. Among them, there are those who have one child, a job, have no problems with their health and the health of their children. Other parents are not sure that they can overcome the difficulties independently: 44.5 per cent believe that "only certain problems" can be solved independently; 41.3 per cent of parents are convinced that it is not able to solve family problems and they need outside help.

Divorced parents need material (56.2 per cent), social education (23.1 per cent) and psycho-educational (32.4 per cent) help, and socio legal (12.6 per cent) and medical-social (11.8 per cent) help.

It is impossible not to pay attention to those responses that recognize the need for the divorce. The respondents have reported the following reasons that allow it: the deviant behavior of one of the parents (alcoholism, drug abuse, gambling, prostitution) - 97.1 per cent; the treason - 95.4 per cent; the presence of another family of one family member -85.5 per cent; the incompatibility of nature and views -72.3 per cent; the love to another women / men - 50.1 per cent; the situation of intervention and family life of others -22.1 per cent; the involuntary separation - 19.3 per cent; the different views on the education of children - 17.2 per cent; the tangible insecurity -11.5 per cent. The situation of the marriage dissolution because 
of a serious illness of a spouse, the presence of non-native children, dissatisfaction in sexual terms, the absence of common living, the desire to have children with another man, the birth of a disabled child as reasons that could justify a divorce, call from 4.7 per cent to 1.3 per cent of the respondents.

The question, which also proved to be controversial, touched the need to preserve the family for the child. Only 8.2 per cent of respondents gave a positive answer: "Yes, in any circumstances"; the overwhelming majority of respondents do not consider the presence of a child a serious obstacle to divorce. The percentage of those adults who believe that divorce is better than a formal family for a child is rather significant - it is 48.1 per cent of the parents.

The position of children in a divorce situation of the parents were the other - they try to reconcile their parents, even if the relationships between parents are difficult. Thus, the respondents ' answers to the survey question: "What methods of reconciliation you and your husband / wife did your children use to prevent a divorce?" showed that children seek parents reconciliation: tantrums, crying; ultimatums; the stories about their success in a preschool institution; the organization of joint family holidays; the request to both parents to help, the request to go along to visit another family; the conversations with each of the parents about the benefits of the other.

The survey results allow confirming that the preventive measures are not effective because of the difficulty in timely identification of problem situation - at the early stages. Therefore, we have to identify families "at risk" on the fact of the divorce for introducing the preventive measures. The complexity of this detection is because the couple have not consulted with the specialists and solve these problems with the relatives (58.4 per cent), the neighbors, colleagues at work (41.6 per cent); the friends who have been in that situation (35.6 per cent); the ex-husband (wife) - 15.4 per cent. Respectively 24.5 per cent and 26.7 per cent of respondents have called social pedagogues and psychologists among the professionals who can appeal, and the highest number of answers has been given to educators of children of preschool age -35.5 per cent. This result can be explained, first of all, the close interaction at different stages of the divorce of the parents with the caregiver of a child who attends preschool, as well as the insufficient number of social pedagogues and practical psychologists in such establishments and their employment in other areas of social and educational activities. However, the integrated application of these specialists of compensation 
technologies, such as social adaptation to the situation of divorce and rehabilitation is important at the stage of the divorce process and after it.

It is worth emphasizing that children's adaptation to the rupture of family ties between father and mother is extremely difficult. The parents call a significant number of factors that affect the adaptation of the children to the situation of divorce in particular. They are: the nature and amount of information, which the child know, about the divorce, its causes and consequences (47.2 per cent); the circumstances under which a child has learned about the situation of the parental divorce (45.1 per cent); the break of the relations with relatives of the parent who lives separately (44.7 per cent); the breaking ties with families, friends and their children because of the change of living place (43.3 per cent); and the reaction of entourage on divorce in general and of children from the families of divorced parents in particular (42.1 per cent), etc.

So, the social adaptation of the children in a situation of parental divorce is accompanied by many factors that can complicate this process. The situation requires the right behavior, endurance, wisdom of parents in respect of interaction with the child at this stage, and the need to provide qualified assistance to families by professionals.

\section{Findings}

Thus, we can conclude that both parents and their children in a divorce situation need effective social rehabilitative specialist help from the social services in various fields. But the level of socio-rehabilitative work with them is not sufficient. As the practice shows, the solution to the problem of a complex institutional, socio-pedagogical, psychological, legal, financial-material support of rehabilitative activities with divorced families is impossible without a deep study of the negative consequences of the divorce, the development of interventions to minimize them, as well as an active practice on the part of local and regional authorities. At the same time, it is worth noting that both scientific development and practical solution of the problem is significantly complicated by the fact that in social practice many social institutions and organizations, in which there are significant discrepancies and inconsistencies, are involved to its solution.

We are also interested in the opinion of experts and survey respondents about the quality of preventive and rehabilitative measures of the children and their divorced parents that are held by the specialists of preschool edu- 
cational institutions. According to most experts, the work on socio-psychological support for the children and parents, as well as providing socio-pedagogical support for parents is arranged at an insufficient level. This situation suggests that the situation is caused by the total load of teachers, shortage of specialists in the area of family and social pedagogy, and the lack of social pedagogues and practical psychologist in most institutions, who should act as the main organizers, coordinators and supervisors of preventive and rehabilitative measures with children of divorced families and their parents. Another important shortcoming, which causes complex of consequences, is the lack of programs of social-psychological-pedagogical work with this category of children and parents.

\section{Conclusions}

The analysis of psycho-pedagogical work allowed concluding that social characteristics of children experiencing the divorce of their parents reveal the negative nature of its influence on the child's personality. The parental divorce reduces the number of family communication, limits the full functioning of the family and affects inevitably at the socialization of children, inadequate assimilation of the sex-role attitudes and behaviors.

The scientists have identified two vectors of negative consequences of the parental divorce for the socialization of children - short term and long term. The first is connected with the peculiarities of children's reactions to conflict between parents, which growing to maximum before the divorce, the procedure of the divorce and adaptation after it. The long-term impact of the divorce is caused by the accumulation of the defect of the lack of male influence of the father in the upbringing and socialization of the child for many years.

In addition, a few specific features in the life of a child related to the fact that a family has only one parent are highlighted, namely: firstly, the state of one of the parents, who will feel lack of moral, social and material support of the other spouse. Single father has to seek some help outside the family. The society, in turn, will affect unmarried mother and her husband who has left the family. Secondly, the child is exposed to social discrimination associated with the absence of father or mother. Thirdly, the child is deprived of the opportunity to observe a close and harmonious relationship between two adults that can affect his/her own marriage. Fourthly, if there is a parent of the opposite sex with a child in the family, she/he will have no ability of gender identity. 


\section{The divorce problems: reasons and their consequences for the socialization...}

\section{References:}

1. Andreeva T. V. (2004) Semeynaya psikhologiya [Family psychology]. St. Petersburg: Rech'. (in Russian).

2. Balashov V. A. (1987) Oblik sovremennoy sem'i [The image of a modern family]. Moscow; Saransk: Mordovian Book. (in Russian).

3. Vidra D. (2000) Pomoshch' razvedennym roditelyam i ikh detyam: ot tragedii $k$ nadezhde. Po stranitsam nauchnykh trudov Gel'muta Figdora [To help divorced parents and their children: from tragedy to hope. On pages of scientific works of Helmut Figodor]. Moscow: Institut Psikhoterapii. (in Russian).

4. Vitek K. (1988) Problemy supruzheskogo blagopoluchiya [The problems of marital well-being]. Moscow: Mysl'. (in Russian).

5. Grigor'eva E. (1995) Deti posle razvoda [Children after divorce]. Family and school, no. 5, pp. 18-19.

6. Grishina O.V. (2008) Vliyanie razvoda roditeley na veroyatnost' razvoda detey [Influence of parents' divorce on the probability of divorce of children]. Rossiyskiy ekonomicheskiy zhurnal [Russian economic journal] (electronic journal), no. 6, pp. 29-41. Retrieved from: http://www.e-rej.ru/Articles/2009/Grishina. pdf c. 7 (accessed 10 January 2014)

7. Dal' V. I. (1982) Tolkovyy slovar' zhivogo velikorusskogo yazyka [Explanatory dictionary of the living Great Russian language]. no. 3. Moscow: Tsitadel'. (in Russian).

8. Dement'eva I. F. (2001) Negativnye faktory vospitaniya detey v nepolnoy sem'e [Negative factors of upbringing of children in an incomplete family]. Socis, no. 11 , pp. 108-113.

9. Dement'eva I. F. (2000) Razvod i deti [The divorce and children]. Moscow: Gosudarstvennyy NII sem'i i vospitaniya. (in Russian).

10. Demurova N. (2000) Mezh dvukh ogney [Between the devil and the deep sea]. Family and school, no. 4, pp. 18-21.

11. Derzhavna sluzhba statystyky Ukrainy (electronic journal), Retrieved from: http://www.ukrstat.gov.ua/ (accessed 25 february 2015)

12. Dol'to F. (1997) Na storone rebenka [On the side of the child]. St. Petersburg: Peterburg-XXI vek. (in Russian).

13. Enikeeva D. (1998) Neschastlivyy brak [Unhappy marriage]. Moscow: RIPOL KLASSIK. (in Russian).

14. Il'in V. A. (2002) Arkheologiya detstva: Psikhologicheskie mekhanizmy semeynoy zhizni [Archeology of Childhood: The Psychological Mechanisms of Family Life]. Moscow: Nezavisimaya firma "Klass". (in Russian).

15. Koats D. (2000) Budushchee sem'i [The future of the family]. Vperedi XXI vek: perspektivy, prognozy, futurologi. Antologiya sovremennoy klassicheskoy prognostiki. 1952-1999 [Ahead of the XXI century: prospects, forecasts, futurists. Anthology of modern classical prognostics. 1952-1999]. Moscow: Academia. pp. 452-455.

16. Konusov Yu. A. (1986) Vozmozhnost' kompensatsii negativnykh posledstviy razvoda dlya detey [The possibility of compensating for the negative consequences of divorce for children]. Sem'ya kak ob"ekt sotsial'noy politiki [The family as an object of social policy]. Moscow: ISI AN SSSR. pp. 153-164. 
17. Koroleva T. (1999) Povtornyy brak materi i ee otnosheniya s rebenkom [Remarriage of the mother and her relationship with the child]. Proceedings of the Sotsial'naya rabota: opyt i perspektivy (Russia, Moscow, 1999), Moscow: Sotsial'no-tekhnologicheskiy institute, pp. 29-34.

18. Korchagina I. I., Prokof'eva L. M. (2009) Vzaimootnosheniya roditeley i detey: usloviya semeynoy sotsializatsii [Relationship between parents and children: the conditions of family socialization]. Sem'ya $v$ tsentre sotsial'no-demograficheskoy politiki [The family in the center of socio-demographic policy]. Moscow: Nezavisimyy institut sotsial'noy politiki, pp. 47-72. (in Russian).

19. Kochetkova O., Rusakova E., Yanovskiy K. (2007) Krizis instituta sem'i v postindustrial'nom obshchestve : analiz prichin $i$ vozmozhnosti ikh preodoleniya [The crisis of the family institution in a post-industrial society: an analysis of the causes and the possibility of overcoming them]. Moscow: IEPP. (in Russian).

20. Kuznetsova E. V. (2003) Sotsializatsiya detey v sem'yakh razvedennykh roditeley [Socialization of children in families of divorced parents] ( $\mathrm{PhD}$ Thesis), Saransk

21. Marova Z. (1980) Rebenka vospityvaet odna mat' [Child is brought up by one mother]. Vospitanie detey $v$ nepolnoy sem'e [Parenting in an incomplete family], Moscow: Progress, pp. 6-68.

22. Mateychik Z. Nekotorye psikhologicheskie problemy vospitaniya detey $\mathrm{v}$ nepolnoy sem'e [Some psychological problems of raising children in an incomplete family]. Vospitanie detey $v$ nepolnoy sem'e [Parenting in an incomplete family]. Moscow: Progress, pp. 315.

23. Mikhaylova N. (2000) Mezh dvukh ogney [Between the devil and the deep sea]. Family and school, no. 7-8, pp. 12-15.

24. Naselennya Ukraini (2012) [Population of Ukraine]. Kyiv: Informatsiinoanalitychne ahentstvo.

25. Naselennya Ukraini. Sotsialno-demohrafichni problemy ukrainskoho sela. (2007) [Population of Ukraine. Socio-demographic problems of the Ukrainian village]. Kyiv: Instytut demohrafii ta sotsialnykh doslidzhen NAN Ukrainy.

26. Pryrodnyi rukh naselennia 2016 rik: statystychnyi biuleten (2017) [Natural population movement, 2016: statistical bulletin]. Kyiv: Informatsiino-analitychne ahentstvo.

27. Prokof'eva L. M., Valetas M.-F. (2002) Ottsy i ikh deti posle razvoda [Fathers and their children after the divorce]. Socis, no. 6, pp. 111-115.

28. Ratter M. (1987) Pomoshch' trudnym detyam [Help to difficult children]. Moscow: Progress. (in Russian).

29. Rudenko I. M. (2009) Vplyv rozluchennia batkiv na zhyttiediialnist dytyny molodshoho shkilnoho viku [Influence of divorce of parents on the vital activity of a child of junior school age]. (PhD Thesis), Kyiv.

30. Savinov L. I., Kamyshova E. V. (2008) Sotsial'naya rabota s det'mi v sem'yakh razvedennykh roditeley [Social work with children in families of divorced parents]. Moscow: "Dashkov i Ko". (in Russian).

31. Semychenko V. A., Zasluzheniuk V. S. Mystetstvo vzaiemorozuminnia. Psykholohiia ta pedahohika simeinoho spilkuvannia (1998) [The art of mutual understanding. Psychology and pedagogy of family communication]. Kyiv: Veselka. (in Ukrainian). 


\section{The divorce problems: reasons and their consequences for the socialization...}

32. Sinel'nikov A. B. (1993) Problemy nepolnykh semey v sovremennoy Rossii [The problems of incomplete families in modern Russia]. Proceedings of the Sem'ya v protsesse razvitiya (Russia, Moscow, November 18-19, 1993), Moscow: NIIsem'i Minsotszashchity Rossii, p. 193.

33. Davydov Yu. N., Kovaleva M. S., Filippov A. F. (1990) Sovremennaya zapadnaya sotsiologiya : slovar' [Contemporary Western sociology: a dictionary]. Moscow: Politizdat. (in Russian).

34. Solov'ev N. Ya. (1970) Razvod, ego faktory, prichiny, povody [The divorce, its factors, causes, reasons]. Problemy byta, braka $i$ sem'i [The problems of life, marriage and family]. Vilnius: Mintis, pp. 111-127.

35. Stukolova M. (2000) Semeynye konflikty i ikh osobennosti [Family conflicts and their characteristics]. Questions of Psychology, no. 4, pp. 24-29.

36. Figdor G. (1995) Deti razvedennykh roditeley: mezhdu travmoy i nadezhdoy [Children of divorced parents: between trauma and hope]. Moscow: Nauka. (in Russian).

37. Florko L. (2006) Sotsialna samotnist suchasnoi liudyny yak filosofska problema [Social solitude of modern man as a philosophical problem]. Sociohumanitarian problems of man, no. 2, pp. 31-46.

38. Fomin F. V. Evoliutsiia simeino-shliubnykh stosunkiv u suchasnomu suspilstvi (2012) [Evolution of family-marital relations in modern society]. Science. Religion. Society, no. 3, pp. 82-88.

39. Kharchev A. G., Matskovskiy M. S. (1978) Sovremennaya sem'ya i ee problemy (Sotsial'no-demograficheskoe issledovanie) [Modern family and its problems (Socio-demographic study)]. Moscow: Statistika. (in Russian).

40. Kholostova E. I. (1997) Sotsial'nyy institut [Social Institute]. Rossiyskaya entsiklopediya sotsial'noy raboty [Russian Encyclopedia of Social Work]. Moscow: Tsentr obshchechelovecheskikh tsennostey, vol. 2, pp. 321-324.

41. Khorvat F. (1982) Lyubov. Materinstvo. Budushchee [Love. Motherhood. The future]. Moscow: Progress. (in Russian).

42. Tseluyko V. M., Vasilenko A.V., Dement'eva E.A. (1999) Nepolnaya sem'ya: psikhologicheskie i sotsial'no-pravovye osobennosti; formy $i$ metody psikhologicheskoy i sotsial'noy raboty [Incomplete family: psychological and socio-legal features; forms and methods of psychological and social work]. Volgograd: Volgogradskiy universitet. (in Russian).

43. Tseluyko V. M. (2004) Psikhologiya neblagopoluchnoy sem'i [Psychology of a Dysfunctional Family]. Moscow: VLADOS-PRESS. (in Russian).

44. Institute of Demography and Social Studies National Academy of Sciences of Ukraine (2008) Shliub, simia ta ditorodni oriientatsii v Ukraini [The marriage, family and childbearing orientation in Ukraine]. Kyiv: ADEF-Ukraina (in Ukrainian).

45. McLanahan S., Bumpass L. (1988) Intergenerational Consequences of Family Disruption. The American Journal of Sociology, vol. 94, no.1, pp. 130-152.

46. Strong Br., DeValt Ch., Sayad B. (1998) The marriage and family experience: Intimate relationships in a changing society. - Belmont, CA: Wadsworth, 1998. (in English). 